\title{
In situ measurements of cloud microphysical and aerosol properties during the break-up of stratocumulus cloud layers in cold air outbreaks over the North Atlantic
}

\author{
Gary Lloyd $^{1,2}$, Thomas W. Choularton ${ }^{2}$, Keith N. Bower ${ }^{2}$, Martin W. Gallagher ${ }^{2}$, Jonathan Crosier ${ }^{1,2}$, \\ Sebastian O'Shea ${ }^{1}$, Steven J. Abel ${ }^{3}$, Stuart Fox ${ }^{3}$, Richard Cotton ${ }^{3}$, and Ian A. Boutle ${ }^{3}$ \\ ${ }^{1}$ NERC National Centre for Atmospheric Science (NCAS), Leeds, UK \\ ${ }^{2}$ Centre for Atmospheric Science, University of Manchester, Manchester, UK \\ ${ }^{3}$ Met Office, Exeter, UK \\ Correspondence: Gary Lloyd (gary.lloyd@manchester.ac.uk)
}

Received: 1 June 2018 - Discussion started: 4 July 2018

Revised: 28 September 2018 - Accepted: 21 October 2018 - Published: 5 December 2018

\begin{abstract}
A key challenge for numerical weather prediction models is representing boundary layer clouds in cold air outbreaks (CAOs). One important aspect is the evolution of microphysical properties as stratocumulus transitions to open cellular convection. Abel et al. (2017) have shown, for the first time from in situ field observations, that the break-up in CAOs over the eastern Atlantic may be controlled by the development of precipitation in the cloud system while the boundary layer becomes decoupled. This paper describes that case and examines in situ measurements from three more CAOs. Flights were conducted using the UK Facility for Airborne Atmospheric Measurements (FAAM) British Aerospace-146 (BAe-146) aircraft in the North Atlantic region around the UK, making detailed microphysical measurements in the stratiform boundary layer. As the cloudy boundary layer evolves prior to break-up, increasing liquid water paths (LWPs) and drop sizes and the formation of liquid precipitation are observed. Small numbers of ice particles, typically a few per litre, are also observed. Eventually LWPs reduce significantly due to loss of water from the stratocumulus cloud (SC) layer. In three of the cases, aerosols are removed from the boundary layer across the transition. This process appears to be similar to those observed in warm clouds and pockets of open cells (POCs) in the subtropics. After break-up, deeper convective clouds form with bases warm enough for secondary ice production (SIP), leading to rapid glaciation. It is concluded that the precipitation is strongly associated with the break-up, with both weakening
\end{abstract}

of the capping inversion and boundary layer decoupling also observed.

\section{Introduction}

Cold air outbreaks (CAOs) frequently impact the North Atlantic region during winter months. While the synoptic evolution of these events is often well forecast by numerical weather prediction (NWP) models, the extent of resulting stratocumulus clouds (SCs) and the transition from closed to open cellular convective regions is often poorly represented. Some of the reasons for this include the depth of the boundary layer and the size of the convective elements in these events approaching model resolution, and the difficulty of parameterizing ice formation processes in these slightly supercooled clouds (cloud bases between $\sim-4$ and $-10^{\circ} \mathrm{C}$ ) (Field et al., 2014).

Abel et al. (2017) used in situ measurements to evaluate cloud resolving simulations of one of the CAOs described in this paper (Case 1). Cloud measurements showed a stratiform region composed primarily of liquid drops and low concentrations of ice particles, typically a few per litre at most. Down-wind cloud morphology changed rapidly, with shallow cumulus clouds developing, leading to enhanced precipitation rates and secondary ice production (SIP). Simulations using the Met Office Unified Model were able to capture some of the cloud properties but unable to reproduce the liquid water path (LWP) that was observed. Sensitivity 
tests showed that ice processes were too active in the model, leading to the removal of too much liquid water. It was also found that decoupling of the boundary layer, triggered by the evaporation of precipitation below the cloud base, was a key process involved in the transition to open cellular convection. In this paper we extend the in situ measurements detailed in Abel et al. (2017) to a further three cases to examine the similarities between the cloud, aerosol and thermodynamic properties in Case 1 and the new cases. The focus in this paper is on the in situ measurements made during the $\mathrm{CAO}$ investigations, and does not extend to model sensitivity tests performed by Abel et al. (2017).

Accurate prediction of CAOs is important as they are common (Kolstad et al., 2009; Fletcher et al., 2016) and bring the potential for severe weather, including heavy rain, snowfall events, damaging winds and lightning. The ability to capture the horizontal extent of low-level SCs in these events, together with an accurate representation of the microphysical properties, is also critical to understanding the impact they have on long- and short-wave radiation budgets (Curry et al., 1996). While this paper focuses on synoptic-scale weather events, the problem of reproducing mid-latitude SCs is an issue in climate modelling, particularly in relation to the Southern Hemisphere $(\mathrm{SH})$ radiation bias, a result of Southern Ocean (SO) clouds not reflecting enough short-wave radiation. Excessive absorbed short-wave radiation biases, particularly over the SO, due to the direct impact of modelled postcold-front SCs not containing enough supercooled liquid water, have been described in previous studies (Bodas-Salcedo et al., 2012; Kay et al., 2016).

Fletcher et al. (2016) provided a useful climatology of marine cold air outbreaks (MCAOs), showing the similarities between these events in both the Northern Hemisphere (NH) and the $\mathrm{SH}$, which suggests the measurements presented in this paper from CAOs in the NH could be applied to improve our understanding in other regions.

Attempts to model low-level boundary layer clouds in Arctic regions frequently find low biases in liquid water content (LWC) values. Klein et al. (2009) compared model simulations of low-level single layer clouds with in situ and remote sensing measurements from the Mixed-Phase Arctic Cloud Experiment (M-PACE) (Verlinde et al., 2007), finding that complex microphysical parameterizations could reproduce observed LWPs, while simpler schemes led to an underestimation. Morrison and Pinto (2006) found that accurate simulation of observed cloud layers was dependent on the microphysics scheme selected. Liu et al. (2011) tested the sensitivity of model simulations to microphysical processes, finding that the underestimation of LWCs was most sensitive to the auto-conversion of small ice to snow and the subsequent depletion of the liquid phase through the WegenerBergeron-Findeisen (WBF) process. Switching this process off over the temperature range of the observed cloud layers led to good agreement with in situ observations. Field et al. (2014) used the Met Office Unified Model to simulate a
CAO during January 2010 and the resulting cloud fields over the North Atlantic. The control model under-predicted LWPs and failed to reproduce the stratiform cloud region. Sensitivity tests found improved simulation when shear-driven vertical turbulent mixing was allowed to extend to the cloud top. Further improvements were found when the threshold for heterogeneous ice nucleation was changed from -10 to $-18^{\circ} \mathrm{C}$ and the efficiency of auto-conversion of cloud water to precipitation was reduced. Abel et al. (2017) showed, that even with many of these improvements included in their control simulation, the stratiform LWP was still too low. Field et al. (2017) also showed that nine leading regional models all struggled to simulate the same SC layer.

In situ observations have often focussed on areas of supercooled SCs in Arctic regions (Verlinde et al., 2007; Lance et al., 2011; Jackson et al., 2012) and report persistent, horizontally extensive regions of cloud consisting of liquid tops that continually precipitate ice. During the Aerosol CloudCoupling And Climate Interactions in the Arctic (ACCACIA) campaign, Lloyd et al. (2015) observed similar cloud properties in the Arctic spring; however, in the summer season, the microphysical properties exhibited greater variability, with stable layer clouds sensitive to the development of drizzle and ice formation processes that were observed to reduce LWPs and to break up the cloud.

During the VOCALS campaign (Wood et al., 2011b), observations of warm SCs were made over the subtropical south-east Pacific, with a focus on persistent SC layers consisting of closed cells and pockets of open cells (POCs) (Stevens et al., 2005) that were embedded within overcast and open cellular regions. Wood et al. (2008) found POCs were most likely to form overnight and at times when aerosol number concentrations were low, suggesting that drizzle played an important role in the transition between closed and open cell structures. Terai et al. (2014) studied POCs in the same region, finding that the ratio of drizzle to cloud water was an order of magnitude larger than in the overcast regions. Wood et al. (2011a) also found that aerosol concentrations in the overcast SC regions were 3 times higher than in a POC they studied. They concluded that, although they did not observe the formation of the POC, SCs with high LWPs are inherently unstable due to coalescence scavenging of cloud condensation nuclei $(\mathrm{CCN})$ that exceeds replenishment rates. Connolly et al. (2013) used a large eddy simulation (LES) to examine the impact of gravity waves on the marine boundary layer (MBL), finding that although the waves do cause additional drizzle formation, the entrainment of warm dry air into the cloud can cause a change from a closed cell structure to a patchy cloud regime. The simulations they performed suggested that $\mathrm{CCN}$ scavenging was unimportant in causing cloud break-up. Boers et al. (1996) found evidence that in warm marine SCs over the Southern Ocean, clouds were depleted by the formation of drizzle that scavenged cloud water through collision coalescence, a process that could be enhanced through the depletion of aerosol 
particles in the boundary layer (Rosenfeld et al., 2008). Others have also highlighted the importance of drizzle formation in model simulations (Boutle and Abel, 2012; Yamaguchi et al., 2017). Bretherton and Wyant (1997) found that, although drizzle did play a role in decoupling, a deepening warming process driven by increasing latent heat fluxes was the main driver for decoupling of the mixed layer in their model simulations of subtropical SCs over a warming sea surface.

Overall, research suggests that a combination of physical properties and processes may play a role in the formation, development and eventual break-up of SC layers during CAOs. These include (i) the dynamical structure of the boundary layer; (ii) surface fluxes of heat and moisture; (iii) entrainment of dry air at the cloud top; (iv) the availability of $\mathrm{CCN}$ and ice nucleating particles (INPs); (v) the microphysical structure, which, in part is controlled by (iv); (vi) the development of both liquid and frozen precipitation particles; (vii) the possible influence of gravity waves on (iii) and (vi).

Adequate description of these in models is key to accurately simulating cloud cover during these events and predicting the impact of the severe weather associated with them. A better understanding of the microphysics that sustain these cloud regions and the factors that lead to their break-up will lead to improved numerical weather prediction and subsequently model estimations of reflected short-wave radiation by these boundary layer clouds.

This paper presents in situ observations during four CAOs of clouds deep within areas of SCs, and in the transition regions that are associated with the eventual evolution to open cellular convection. The main focus is on the microphysics of these cloud layers and the aerosol properties in the boundary layer.

\section{Measurements and data analysis}

The Facility for Airborne Atmospheric Measurements (FAAM) British Aerospace-146 (BAe-146) aircraft was used to perform a combination of straight and level runs (SLRs) and profiles through cloud layers. Dropsondes were deployed to measure the thermodynamic structure of the atmosphere. In situ measurements of cloud microphysical and aerosol properties in each case were provided by a suite of instruments. The configuration varied between flights and included the Three-View Cloud Particle Imager (3V-CPI, Stratton Park Engineering Company (Spec) Inc. Boulder, USA), consisting of two instruments, the two-dimensional stereoscopic (2-D-S) probe, providing $10 \mu \mathrm{m}$ resolution shadow images of hydrometeors over the range $10<d_{\mathrm{p}}<1280 \mu \mathrm{m}$, and a Cloud Particle Imager (CPI) CCD camera that was used to record very high resolution $(2.3 \mu \mathrm{m})$ particle imagery (Cases 3 and 4). A stand-alone 2-D-S (Lawson et al., 2006) was used in Cases 1 and 2. Measurements of larger cloud particles were made using the Cloud Imaging Probe100 (CIP-100, Droplet Measurement Technologies, DMT)
(Baumgardner et al., 2001), which provided $100 \mu \mathrm{m}$ resolution shadow images of cloud hydrometeors over the range $100<d_{\mathrm{p}}<6200 \mu \mathrm{m}$.

Total water content (TWC) (liquid + vapour) was measured at $64 \mathrm{~Hz}$ using a Lyman-Alpha absorption hygrometer (Nicholls et al., 1990). The Cloud Droplet Probe (CDP100 Version-2, DMT, Boulder, USA) (Lance et al., 2010) was used for measurement of the cloud droplet size distribution over the range $3<d_{\mathrm{p}}<50 \mu \mathrm{m}$. Calibration was carried out using glass beads and the data compared to measurements from the Nevzorov liquid water content and total water content probe (LWC + IWC) (Korolev et al., 1999), which was baselined following the method in Abel et al. (2014). We found the TWC probe's LWC and the CDP LWC to be in good agreement for all cases. The $r^{2}$ values for these comparisons were $0.86,0.86,0.93$ and 0.66 respectively. The lower $r^{2}$ value for the final case was due to an instrument issue that was identified using this inter-comparison approach. The Microwave Airborne Radiometer Scanning System (MARSS) (McGrath and Hewison, 2001) was also used for column liquid water retrievals. Additional details on the MARSS LWP retrieval can be found in Abel et al. (2017).

Measurements of the aerosol size distribution were made using the Passive Cavity Aerosol Spectrometer Probe (PCASP-100X, DMT) for particle sizes $0.1<d_{\mathrm{p}},<3 \mu \mathrm{m}$ (Rosenberg et al., 2012). Core instruments on the aircraft included temperature, measured using Rosemount/Goodrich type 102 temperature sensors, and information about aircraft altitude, speed and position was provided by the GPS-aided inertial navigation system.

The shadow imaging probe 2-D-S was used for geometric analysis of particle size and shape. From this information, discrimination between irregular and spherical particles was possible for hydrometeors $>\sim 60 \mu \mathrm{m}$ using a circularity criterion (Crosier et al., 2011). The categories generated using information about a particles shape were low irregular (LI, shape factor between 1 and 1.2), indicating liquid droplets; medium irregular (MI, shape factor between 1.2 and 1.4), for increasingly irregular particles possibly indicative of ice; and high irregular (HI, shape factor of 1.4 and greater), images that have a high shape factor, indicating ice particles.

Data from these instruments were analysed using the Optical Array Shadow Imaging Software (OASIS), which was developed by the National Centre for Atmospheric Science (NCAS) and DMT; further description of this can be found in Crosier et al. (2011). The 2-D-S and CIP-100 were equipped with Korolev anti-shatter tips (Korolev et al., 2011) to reduce shattering artefacts. Examination of inter-arrival time (IAT) histograms was also used to identify and remove shattered particles. The 2-D-S contained within the 3V-CPI instrument used a knife-edge inlet to limit artefacts. Datasets in $1 \mathrm{~Hz}$ format were used to calculate statistics such as mean liquid water content profiles as a function of altitude, and for percentiles in Figs. 6, 10 and 13. 

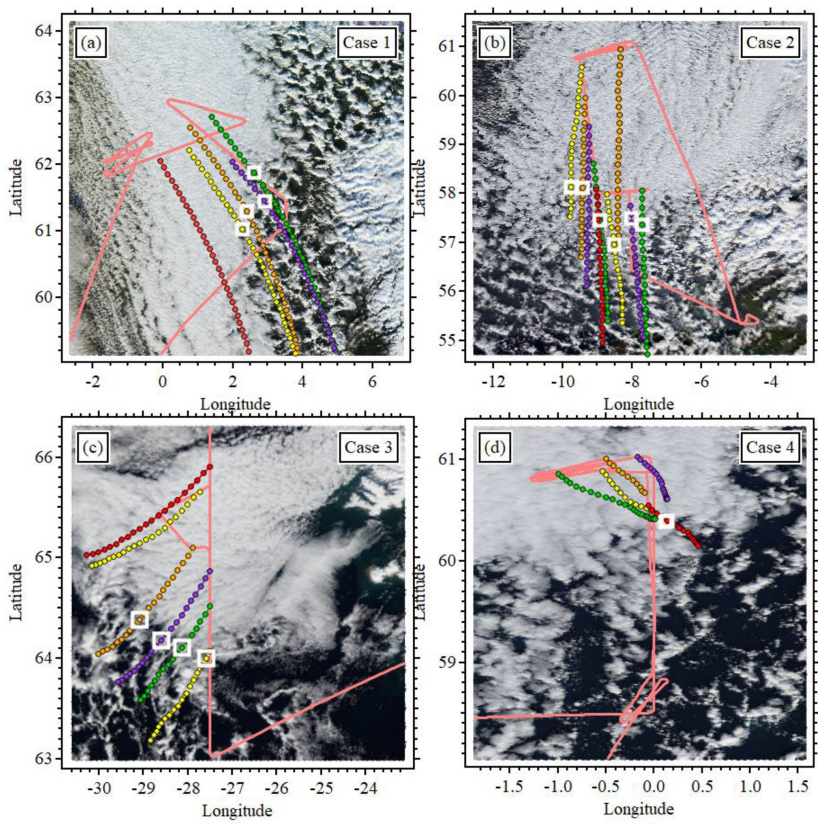

Figure 1. MODIS visible satellite RGB composite images for each case with flight track of the aircraft overlaid (pink lines). Overpass times are 12:00, 12:20, 13:10 and 11:10 UTC respectively. Simulated forward trajectories from the Met Office Unified Model are represented by solid circle symbols; each circle represents a $15 \mathrm{~min}$ time step along the trajectory. White boxes indicate determined cloud break-up location.

\subsection{Microphysical evolution with proximity to the break-up region}

In Cases 1-3 the microphysical properties of the stratiform capped boundary layer were related to the proximity to the transition region to investigate changes in properties of the cloud layers. Forward trajectories using boundary layer winds from the midpoint of each aircraft profile were simulated by the Met Office Unified Model using the same convection permitting model configuration used in Abel et al. (2017). From this, with the use of MODIS satellite data, the distance each profile was situated from the break-up region was estimated, and some of these trajectories are shown as examples overlaid on satellite imagery in Fig. 1, with the estimated location of the break-up highlighted by the white boxes. This information was then used to calculate the median and interquartile ranges for a range of microphysical properties as a function of the distance to the break-up of the SCs. These are presented in Figs. 6, 10 and 13 for Cases 1, 2 and 3 respectively.

In Case 4, profiles through SCs were all made at a similar distance to the break-up as determined by the forward trajectories. For this reason the analysis of changes occurring towards the break-up zone was not carried out for this case.

\section{Observations}

Figure 2 shows ECMWF ERA-5 reanalysis products for surface pressure, $2 \mathrm{~m}$ temperatures, sea surface temperatures and $10 \mathrm{~m}$ wind speeds for four CAOs over the North Atlantic region between 2013 and 2016. Figure 3 shows flight tracks and examples of profile locations numbered on MODIS satellite imagery for each case alongside calculated liquid water paths from the CDP and MARSS. The following sections describe the aerosol and microphysical properties of each case.

\subsection{Case study $1-24$ November 2013}

This is the case that was analysed by Abel et al. (2017). A blocking anticyclone centred to the west of the UK led to a CAO between the north-east coast of the UK and the Norwegian coast (ERA5 Fig. 2a-d). The $10 \mathrm{~m}$ wind speeds were north-north-west at about $12 \mathrm{~m} \mathrm{~s}^{-1}$.

MODIS satellite imagery (Fig. 3a) shows SCs developing off the eastern coast of Greenland, eventually breaking up into open cellular convection towards the Norwegian coastline. The BAe-146 departed from Prestwick $\left(55.51^{\circ} \mathrm{N}\right.$, $4.59^{\circ} \mathrm{W}$ ) before measuring the SC layers, and eventually open cellular convection. A total of 10 profiles were made in the measurement area, with most of these taking place deep within the SC layers before a limited number of profiles were made towards the region of open cellular convection.

In situ measurements revealed a region of SCs below a temperature inversion between 1750 and $2000 \mathrm{~m}$. Dropsonde locations (S1 and S2) are marked on satellite imagery (Fig. 3a), and for this case measured dropsonde profiles were in the stratiform region. LWP values measured by the CDP and MARSS (Fig. 3a) were generally $200-500 \mathrm{~g} \mathrm{~m}^{-2}$ between 10:00 and 10:55 UTC (Fig. 3a). Profile (P) numbers within the stratiform regions of each case are labelled and coloured red in the LWP time series in Fig. 3, and those determined to be close to the transition are shown in black. In the stratiform region cloud tops were 1750-2000 $\mathrm{m}$ and cloud bases were variable between $\sim 1000$ and $1500 \mathrm{~m}$. One profile took place in the cumulus $(\mathrm{CU})$ region where cloud base was about $750 \mathrm{~m}$. The location and temperature of cloud top and cloud bases for each profile are shown in Fig. 4a.

Microphysical properties as a function of altitude for cloud profiles are shown in Fig. 5. These profiles are examples from the overcast region (P5 and P6) compared with measurements made closer to the break-up region. (P8 and P9). The location of these profiles is also marked on the satellite imagery in Fig. 3a.

In the overcast region cloud LWC values measured by the CDP peaked between 0.8 and $1 \mathrm{~g} \mathrm{~m}^{-3}$ (Fig. 5a). Cloud profiles closer to the cloud break-up (indicated by visible satellite data) were found to contain lower LWCs (Fig. 5c), and eventually the aircraft measured a glaciated convective cell with very little liquid water (Fig. 5d). Figure 3a shows the higher LWPs associated with the stratiform region (P6 and 

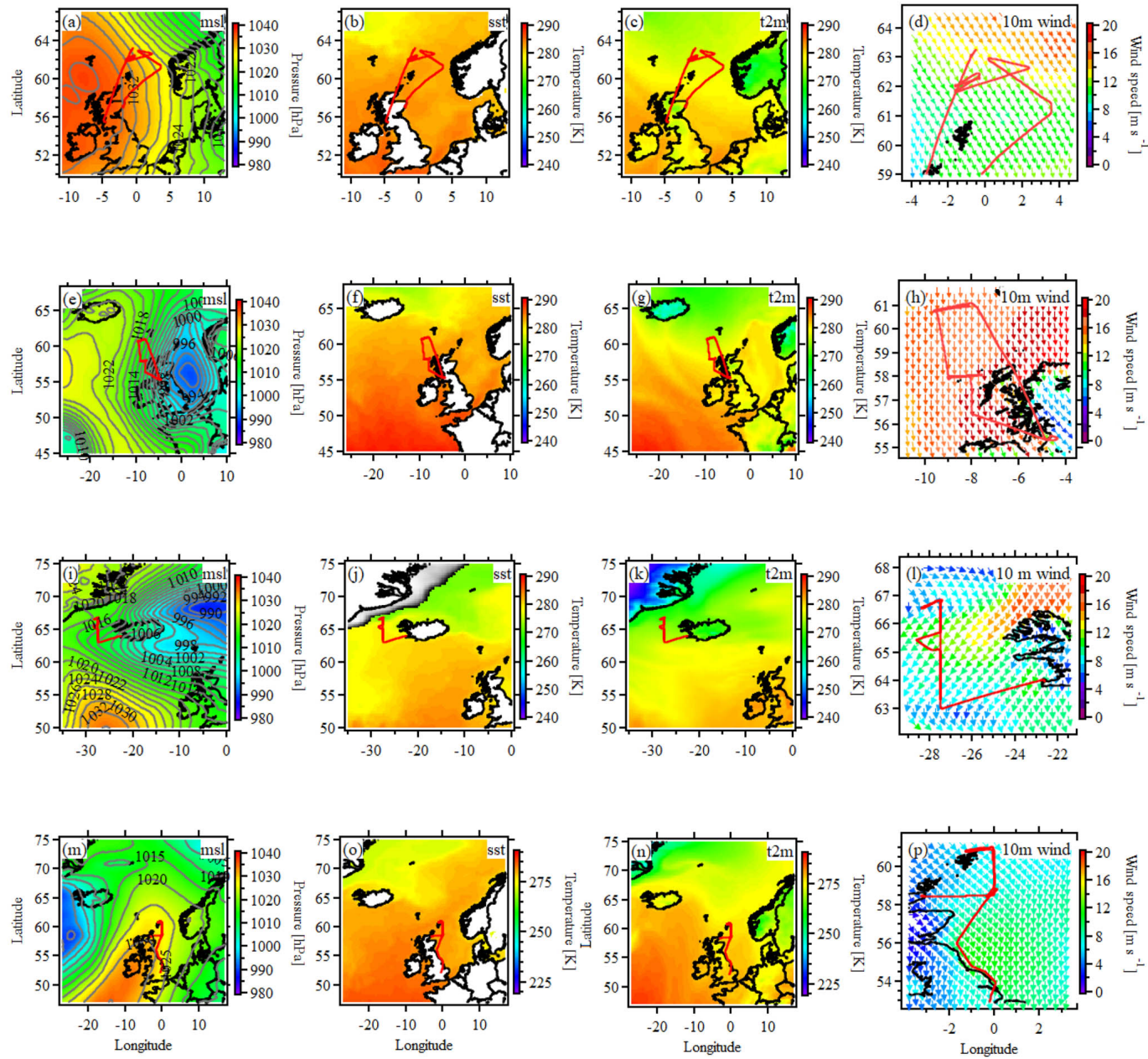

Figure 2. ECMWF ERA5 reanalysis data from each case for mean sea level pressure, sea surface temperatures, $2 \mathrm{~m}$ temperatures and $10 \mathrm{~m}$ wind speed for Case 1 (a-d), Case $2(\mathbf{e}-\mathbf{h})$, Case $3(\mathbf{i}-\mathbf{l})$ and Case $4(\mathbf{m}-\mathbf{p})$.

P7 CDP LWP values 499 and $427 \mathrm{~g} \mathrm{~m}^{-2}$ respectively) and the lower values in the transition and open cellular region $(\mathrm{P} 9$ and P10 CDP LWP values 108 and $17 \mathrm{~g} \mathrm{~m}^{-2}$ respectively).

Figure 6 shows microphysical analysis as described in Sect. 2.1. Quoted microphysical properties are median values. Typical droplet number concentrations were around $100 \mathrm{~cm}^{-3}$ (25th and 75th percentiles 80 and $125 \mathrm{~cm}^{-3}$ respectively) $220 \mathrm{~km}$ away from the break-up deep in the stratiform region. These fell to just $20 \mathrm{~cm}^{-3} 40 \mathrm{~km}$ from the breakup. Cloud droplet sizes were seen to steadily increase from median values of $18 \mu \mathrm{m} 100 \mathrm{~km}$ away to $25 \mu \mathrm{m}$ just $40 \mathrm{~km}$ from the break-up.

These concentrations were in broad agreement with boundary layer aerosol measured by the PCASP that were $84 \mathrm{~cm}^{-3}$ falling to $27 \mathrm{~cm}^{-3} \sim 40 \mathrm{~km}$ from the break-up (Fig. 6d). Vertical profiles showed these particles were well mixed to cloud base (Fig. 5e-h).

Cloud top temperatures were $\sim-15^{\circ} \mathrm{C}$ (Fig. 4a), with little change closer to the break-up region. The cloud base tem- perature did vary between -10 and $-4{ }^{\circ} \mathrm{C}$, with the higher temperatures closer to the break-up as shallow $\mathrm{CU}$ was rising into the SC layer above. Size distributions of cloud droplets were calculated over whole cloud profiles, and a selection from the stratiform region and the transition region are shown in Fig. 7a (P6, green lines and P8, purple lines respectively). The dashed lines represent the very low numbers (peaks of $4 \mathrm{~L}^{-1}$ ) of highly irregular particles identified by the 2-D-S. The size distributions showed a broadening spectrum with increasing proximity to the break-up region. The stratiform region appeared to be dominated by liquid water, with evidence of some ice formation, particularly towards the break-up region. In P8, within the SC region, there was an increase in concentrations of highly irregular particles and a corresponding decrease in LWP (Fig. 5c), indicating ice, with peaks around $4 \mathrm{~L}^{-1}$ measured by the 2 -D-S. The ice crystal images from the 2-D-S and CIP-100 showed the presence of dendritic ice (Fig. 7a). 

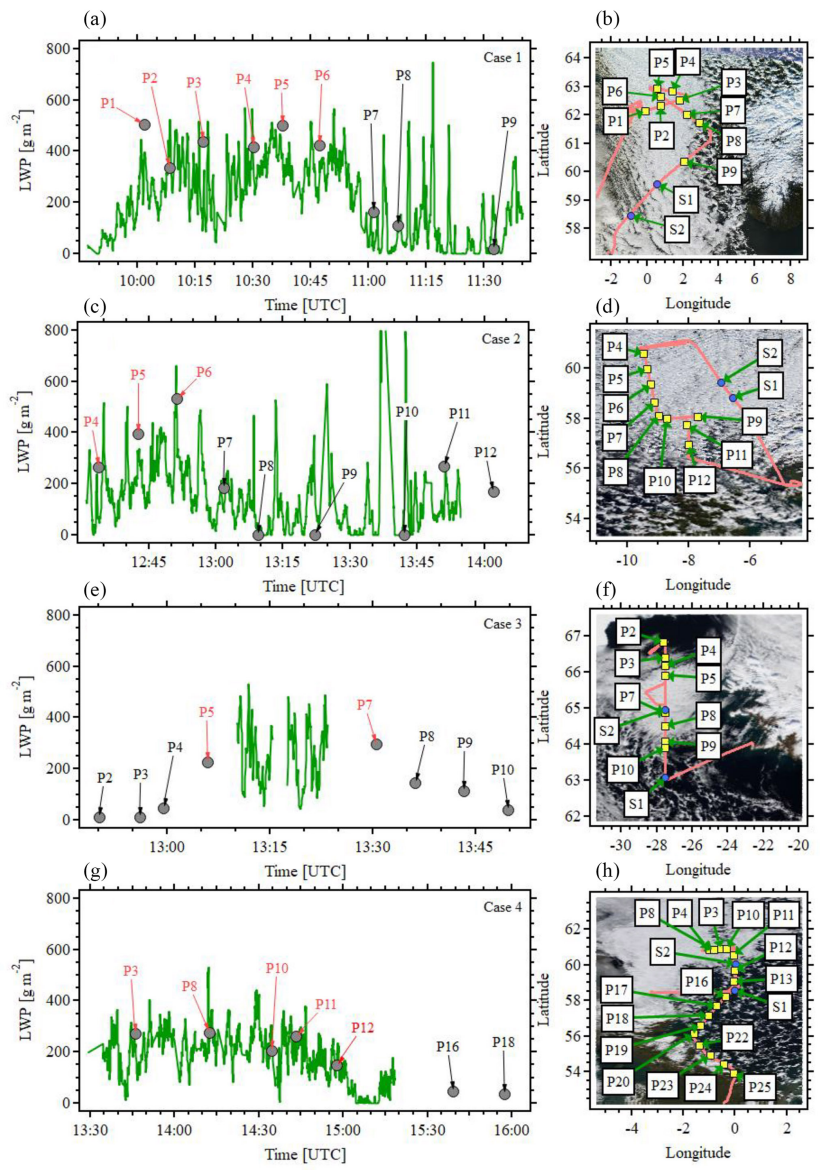

Figure 3. LWP time series values for Cases 1-4 (a, c, e, g) derived from MARSS (green trace) and CDP (grey markers). Red profile numbers indicate stratiform regions and black markers indicate transitioning or open cellular regions. MODIS RGB composite satellite imagery (b, d, f, h) with flight track superimposed (light red trace) and profiles marked (yellow boxes with profile numbers).

The final profile (P9) took place in open cellular convection, just to the south-east of the SC. The aircraft traversed the lower regions of an isolated convective cell. During this profile high concentrations of columnar ice crystals were observed that reached peaks of $120 \mathrm{~L}^{-1}$, with a reduction in liquid water as can be seen in Fig. $5 \mathrm{~d}$.

\subsection{Case study 2 - 20 November 2013}

A CAO affected the North Atlantic region to the north-west of the UK (Fig. 2e-h), with an area of SCs to the north of the UK that transitioned into open cellular convection to the west of Scotland (Fig. 3). A deep area of low pressure produced strong $10 \mathrm{~m}$ winds compared to the other cases in this paper $\left(20 \mathrm{~m} \mathrm{~s}^{-1}\right)$. With the advection of a cold air mass of polar origin, significant cloud formed, overlying the warmer sea surface temperatures. Combinations of straight and level runs
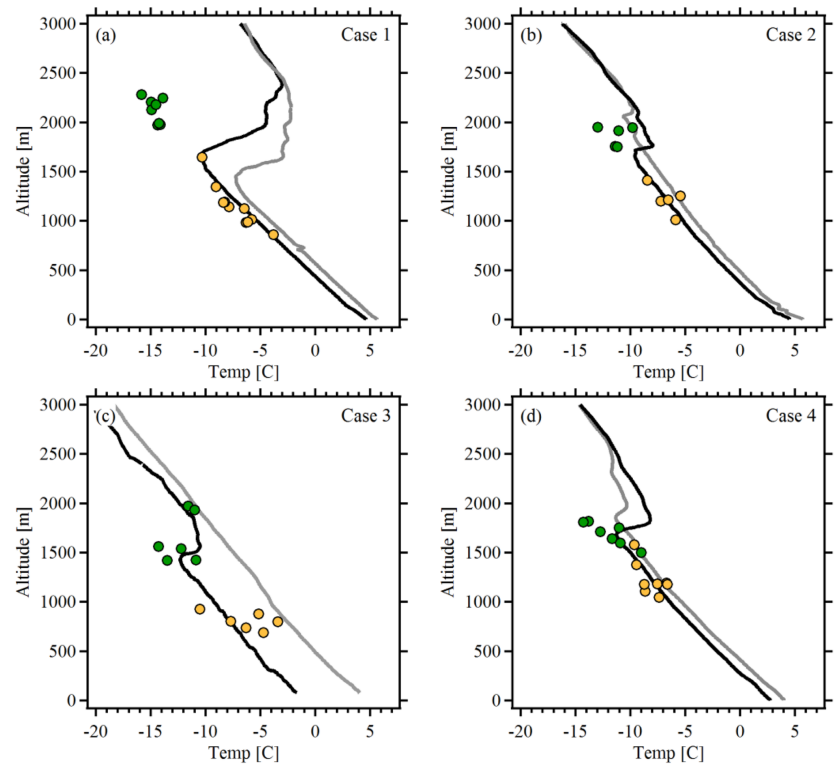

Figure 4. Cloud top altitude and temperature (green symbols), cloud base altitude and temperature (yellow symbols) and dropsonde data for Cases 1-4, showing temperature as a function of altitude. Grey traces represent sonde profiles closer to or in the open cellular regime; black traces represent the stratiform region.

(SLRs) and saw tooth profiles were performed by the BAe146 aircraft after departing from Prestwick.

In situ measurements revealed a region of SCs below the temperature inversion at around $1750 \mathrm{~m}$. Earlier dropsondes deployed by the aircraft (Fig. 4b) had found the inversion to be between about 1500 and $2000 \mathrm{~m}$. Dropsonde locations are marked on satellite imagery (Fig. 3b). Although both dropsondes were within the stratiform region, there is a notable increase in height and weakening of the inversion from the sonde closest to the break-up. LWP values measured by the CDP and MARSS (Fig. 3b) were generally $200-600 \mathrm{~g} \mathrm{~m}^{-2}$ in the stratiform region between $\sim 12: 35$ and 12:55 UTC. Cloud tops were $1750-2000 \mathrm{~m}$ and cloud bases varied between $\sim 10: 00$ and 15:00 m. Cloud top temperatures were between -10 and $-13^{\circ} \mathrm{C}$. Cloud base temperatures were between -5 and $-7^{\circ} \mathrm{C}$. The altitude and temperature of cloud top and cloud bases for each profile is shown on Fig. $4 \mathrm{~b}$.

Microphysical properties as a function of altitude for selected profiles are shown in Fig. 9. These profiles are examples from the overcast region (P5 and P6) compared with measurements made during a profile closer to the break-up region (P12). The location of these profiles is marked on satellite imagery in Fig. 3b. In the stratiform region LWC values peaked $\sim 0.8 \mathrm{~g} \mathrm{~m}^{-3}$ (Fig. 9a-b). Closer to the transition, cloud profiles contained similar peak values but thinner cloud layers. This change is represented in the LWP values of 533 and $393 \mathrm{~g} \mathrm{~m}^{-2}$ in the stratiform region (P5 and P6 

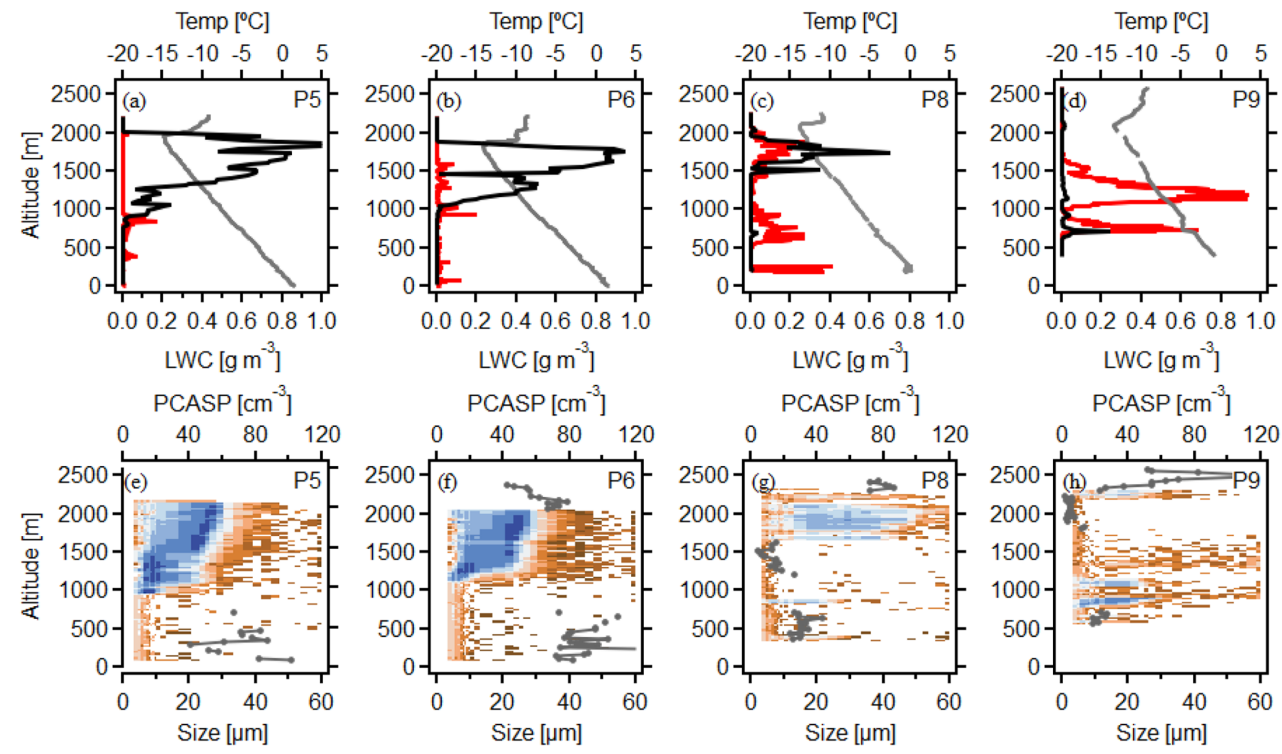

LWC $\left[\mathrm{g} \mathrm{m}^{-3}\right.$ ]

PCASP $\left[\mathrm{cm}^{-3}\right]$

$\mathrm{LWC}\left[\mathrm{g} \mathrm{m}^{-3}\right]$
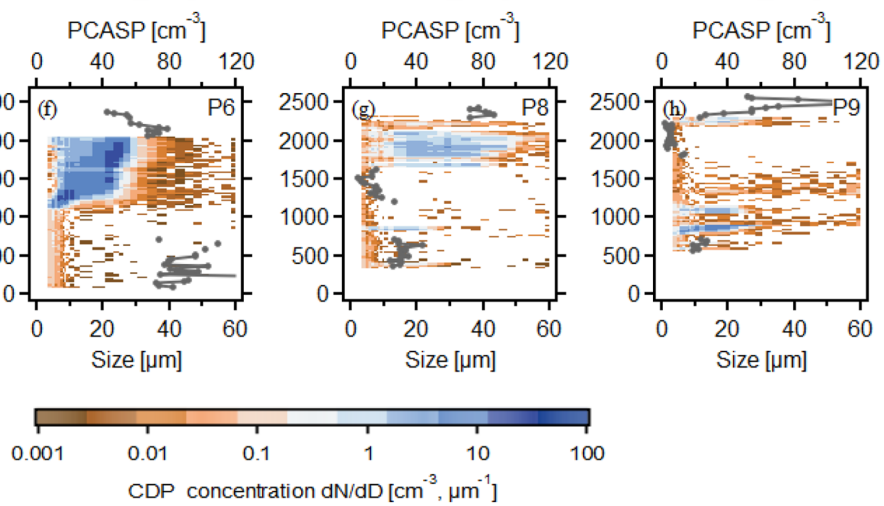

Figure 5. Measurements from Case 1 showing mean LWC as a function of altitude from the CDP (black trace), IWC from the Nevzorov (red trace) and temperature (grey trace) as a function of altitude (a-d). Panels (e-h) show CDP droplet size distributions (colour plot) and mean PCASP concentrations out of cloud as a function of altitude (grey trace).
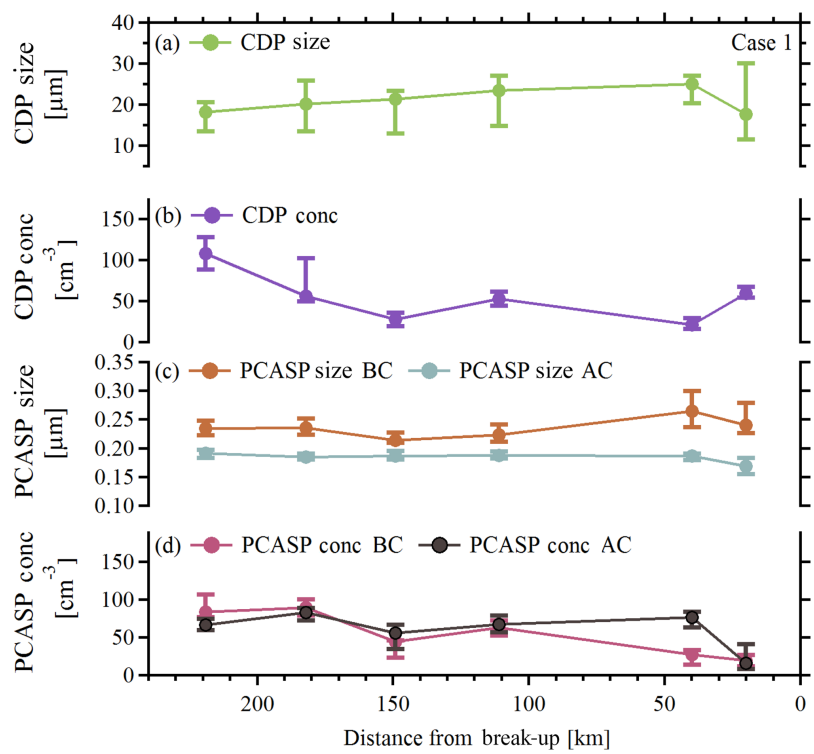

Figure 6. Median and 25th and 75th percentile values as a function of distance from the break-up for (a) CDP size, (b) CDP concentration, (c) PCASP size below cloud (BC) and above cloud (AC) and (d) PCASP concentration BC and AC. respectively marked on Fig. 3b) compared with $269 \mathrm{~g} \mathrm{~m}^{-2}$ closer to the transition in P12.

Figure 10 shows microphysical analysis as described in Sect. 2.1. Quoted microphysical properties are median values. Droplet number concentrations did not show the same trends as in Case 1. There was a general increase in concentrations ( $\sim 60$ at $400 \mathrm{~km}$ from the break-up to $100 \mathrm{~cm}^{-3}$ at $100 \mathrm{~km}$ away) and sizes (10 at $400 \mathrm{~km}$ to $20 \mu \mathrm{m}$ at $100 \mathrm{~km}$ from the break-up, respectively) of cloud droplets with increasing proximity to the transition. There was also an increase in aerosol concentrations $\left(\sim 30\right.$ to $60 \mathrm{~cm}^{-3}$ in the boundary layer). The reasons for this are not clear; however, compared to the other three cases, wind speed measurements were relatively high, $\sim 25 \mathrm{~m} \mathrm{~s}^{-1}$ (compared to $10 \mathrm{~m} \mathrm{~s}^{-1}$ in Cases 1, 34) in the boundary layer close to the sea surface. These strong boundary layer winds can be seen in Fig. $2 \mathrm{~h}$. The strength of the winds in this case may have had an impact on the production of sea salt aerosol from the surface.

A selection of PSDs from the stratiform region and the transition region are shown in Fig. 7b. They show a small increase in the number of precipitation particles measured by the 2-D-S just before the break-up. The number of larger particles, indicating drizzle, increased from 10 to $88 \mathrm{~L}^{-1}$ between P6 and P12 respectively, with the number of HI particles, indicating ice crystals, only increasing from 0.1 to $0.2 \mathrm{~L}^{-1}$. Imagery showed this to be a mix of supercooled drizzle, graupel-type particles and columnar ice crystals. 

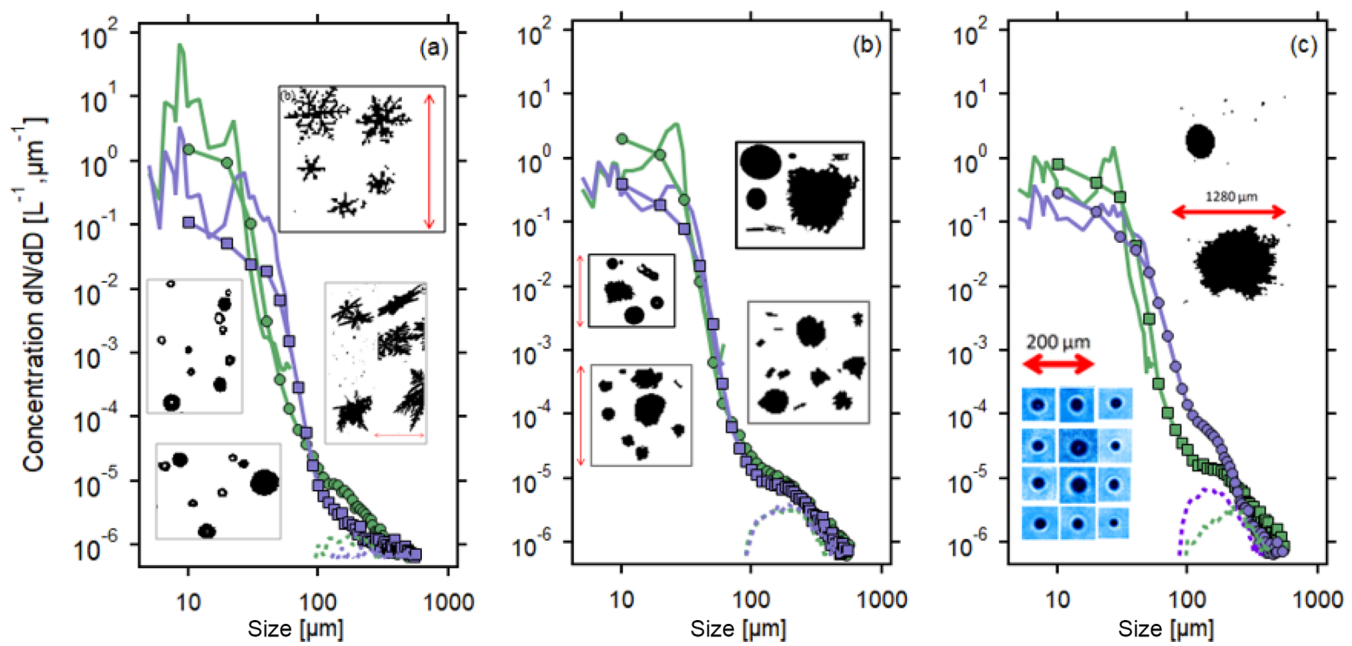

Figure 7. Size distributions for Cases 1-3 comparing the CDP and 2DS size distributions for cloud profiles within the cloudy region (green lines) and closer to the transition (purple lines). Images are examples of ice particles and liquid droplets/drizzle from profiles represented by PSDs.

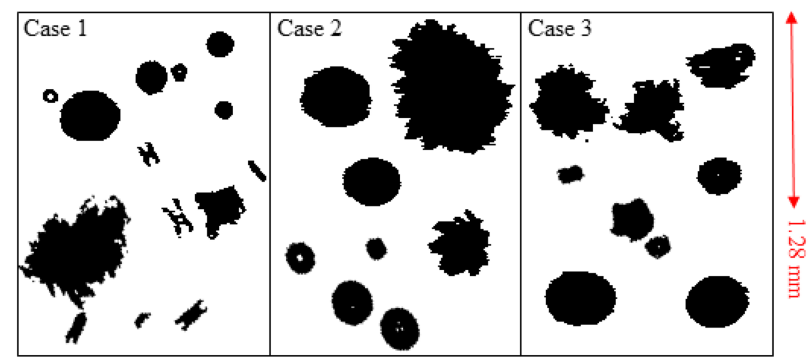

Figure 8. Images from the 2-D-S instrument for Cases 1,2 and 3. Case 1 shows drizzle, rimed ice particles and columnar ice crystals from a period of secondary ice production during P9 (location marked in Fig. 3). Cases 2 and 3 show images from the same periods represented by the particle size distributions in Fig. $7 \mathrm{~b}$ and $\mathrm{c}$.

\subsection{Case study 3 - 23 March 2015}

A CAO affected the North Atlantic region east of Greenland (Fig. 2i-1) with an area of SCs investigated to the west of Iceland using a combination of SLRs and saw tooth profiles that were performed by the BAe-146 aircraft (Fig. 3c). The stratiform region associated with this CAO was significantly smaller in area than the other cases presented in this paper, but had similar microphysical properties. Satellite imagery (Fig. 3c) showed the SC region to the west of Iceland eventually breaking up to the SW of the island. Wind speeds at $10 \mathrm{~m}$ were around $10 \mathrm{~m} \mathrm{~s}^{-1}$.

After the aircraft departed from Keflavic $\left(63.99^{\circ} \mathrm{N}\right.$, $22.62^{\circ} \mathrm{W}$ ) a high-altitude run was carried out with dropsondes (marked on Fig. 3c) used to measure the vertical structure of the atmosphere (Fig. 4c). These measurements revealed an inversion $\sim 1500 \mathrm{~m}$ in the stratiform region, while a drop- sonde in the open cellular region showed that the inversion had been eroded, with associated convection confirmed by satellite imagery.

Cloud top heights in the stratiform region were $\sim 1500 \mathrm{~m}$, while two profiles closer to the break-up showed increased cloud top height close to $2000 \mathrm{~m}$ (Fig. 4c). Cloud top temperatures were between -10 and $-14{ }^{\circ} \mathrm{C}$. Cloud base altitudes were quite closely grouped around $750 \mathrm{~m}$, but the temperatures varied between -3 and $-11^{\circ} \mathrm{C}$. Winds in the boundary layer were north-easterly at $\sim 10 \mathrm{~m} \mathrm{~s}^{-1}$.

Initially, as measurements were made with increasing distance south, a change from a shallow layer of SCs consisting of small liquid cloud droplets to a deeper layer containing larger hydrometeors was observed. LWP values measured by the CDP and MARSS (Fig. 3c) were generally 200 $300 \mathrm{~g} \mathrm{~m}^{-2}$ in the stratiform region $\sim 13: 15$ UTC, with values decreasing significantly closer to the transition from closed to open cell conditions.

Microphysical properties as a function of altitude for selected profiles are shown in Fig. 11. These profiles show some examples from the overcast region (P2, P4, P5 and P7) compared with measurements made closer to the break-up region (Fig. 12; P9 and P10). In P5 and P7, LWC values measured by the CDP peaked at $0.7 \mathrm{~g} \mathrm{~m}^{-3}$ (Fig. $11 \mathrm{c}-\mathrm{d}$ ). P9 and 10 close to the transition showed reductions in LWC values to $0.3 \mathrm{~g} \mathrm{~m}^{-3}$ by P10 (Fig. 12b). LWPs were also seen to decrease to $37 \mathrm{~g} \mathrm{~m}^{-2}$ in P10. P2 and P4 (Fig. 3c) are north of where the most extensive cloud layers were observed. In this region the boundary layer appeared to have become decoupled with a double temperature inversion present.

Figure 13 shows microphysical analysis as described in Sect. 2.1. Quoted microphysical properties are median values. Droplet number concentrations were around $50 \mathrm{~cm}^{-3}$ 

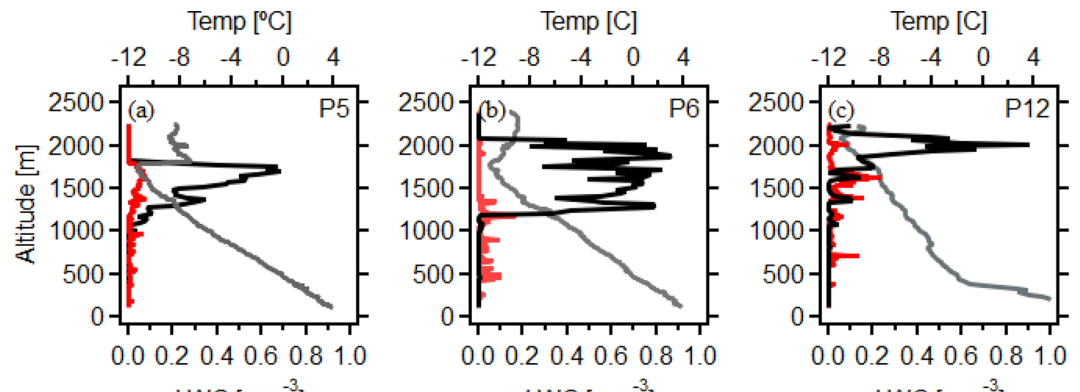

LWC $\left[\mathrm{g} \mathrm{m}^{-3}\right]$

PCASP $\left[\mathrm{cm}^{-3}\right.$ ]

LWC $\left[\mathrm{g} \mathrm{m}^{-3}\right.$ ]

PCASP $\left[\mathrm{cm}^{-3}\right]$

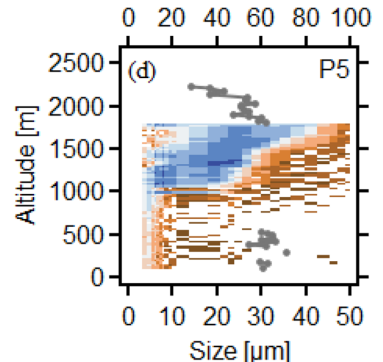

$0 \quad 20 \quad 4060 \quad 80100$

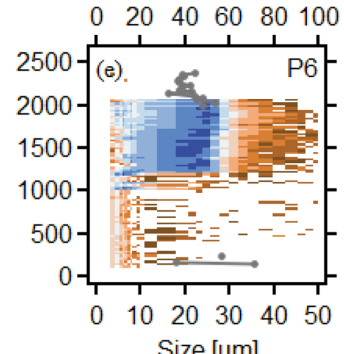

LWC $\left[\mathrm{g} \mathrm{m}^{-3}\right.$ ]

PCASP $\left[\mathrm{cm}^{-3}\right]$
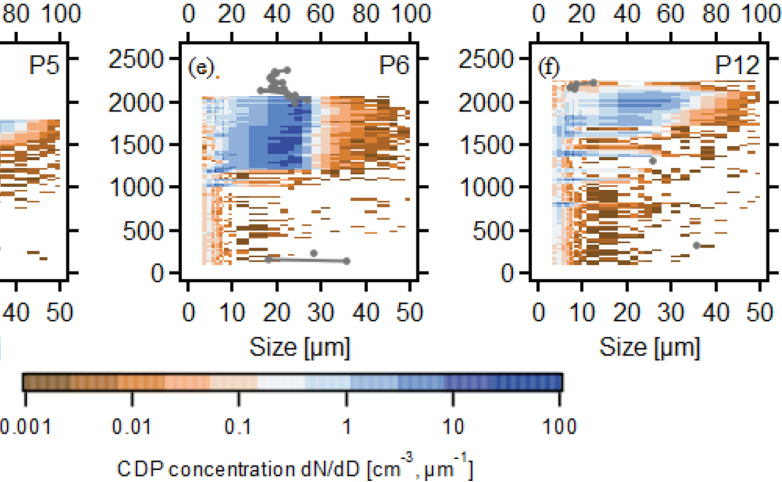

Figure 9. As Fig. 5 but for Case 2.
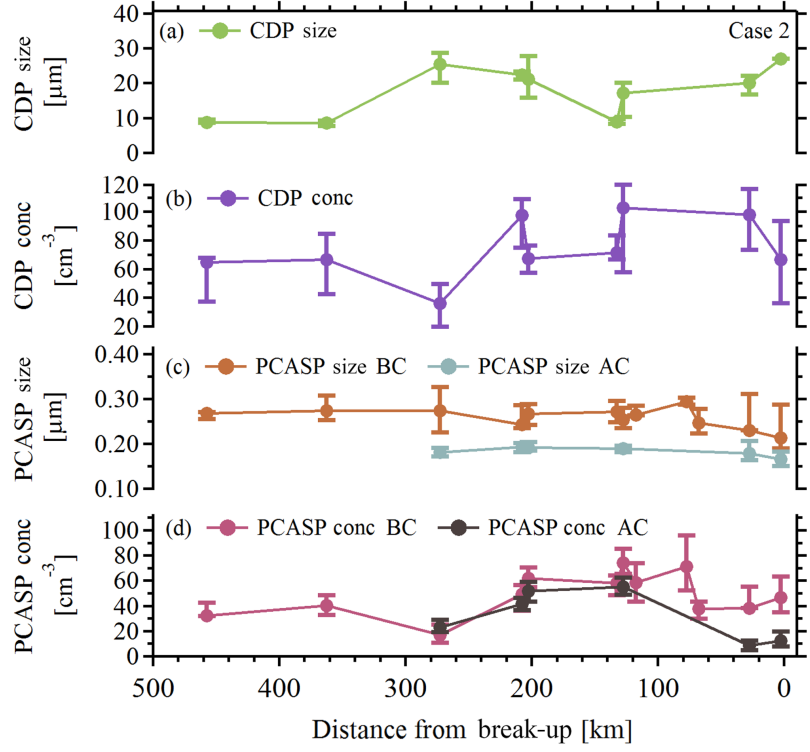

Figure 10. As Fig. 6 but for Case 2.

$\sim 100 \mathrm{~km}$ away from the break-up, but fell significantly to just $15 \mathrm{~cm}^{-3}$ about $50 \mathrm{~km}$ from the transition. PCASP measurements in the boundary layer were complicated by the presence of precipitation; however they also show a large re- duction from $\sim 30 \mathrm{~cm}^{-3}$ at $110 \mathrm{~km}$ to less than $10 \mathrm{~cm}^{-3}$ at around $80 \mathrm{~km}$ from the break-up.

A selection of PSDs from the stratiform region and the transition region are shown in Fig. 7c. Shadow probe and CPI imagery are superimposed on these PSDs as examples of observed particles. The PSDs initially showed a reasonably narrow liquid droplet distribution. As the cloud layer developed, this broadened, and with increasing proximity to the breakup region (Fig. 7c), significant increases in precipitationsized particles consisting of drizzle and irregular ice particles were observed. Despite imagery (superimposed on the size distributions) revealing some irregular particles, the concentrations of ice were generally very low, with the number of counts leading to a high degree of uncertainty due to sampling error; therefore no concentrations are stated for this case. During the final profile, drizzle concentrations increased to $50 \mathrm{~L}^{-1}$ and images from the CPI and 2-D-S revealed spherical liquid drops that were $100-200 \mu \mathrm{m}$ in diameter.

\subsection{Case study 4 - 15 February 2016}

A blocking anticyclone ridged across the UK (Fig. $2 \mathrm{~m}-\mathrm{p}$ ), producing a weak northerly $\left(10 \mathrm{~m}\right.$ winds of $\left.5 \mathrm{~m} \mathrm{~s}^{-1}\right)$ orientated returning polar maritime flow to the north-east of the $\mathrm{UK}$, which produced a $\mathrm{CAO}$ and an $\mathrm{SC}$ region between the north-east coast of the UK and the Norwegian coast. The BAe-146 departed from Cranfield before measuring SC lay- 

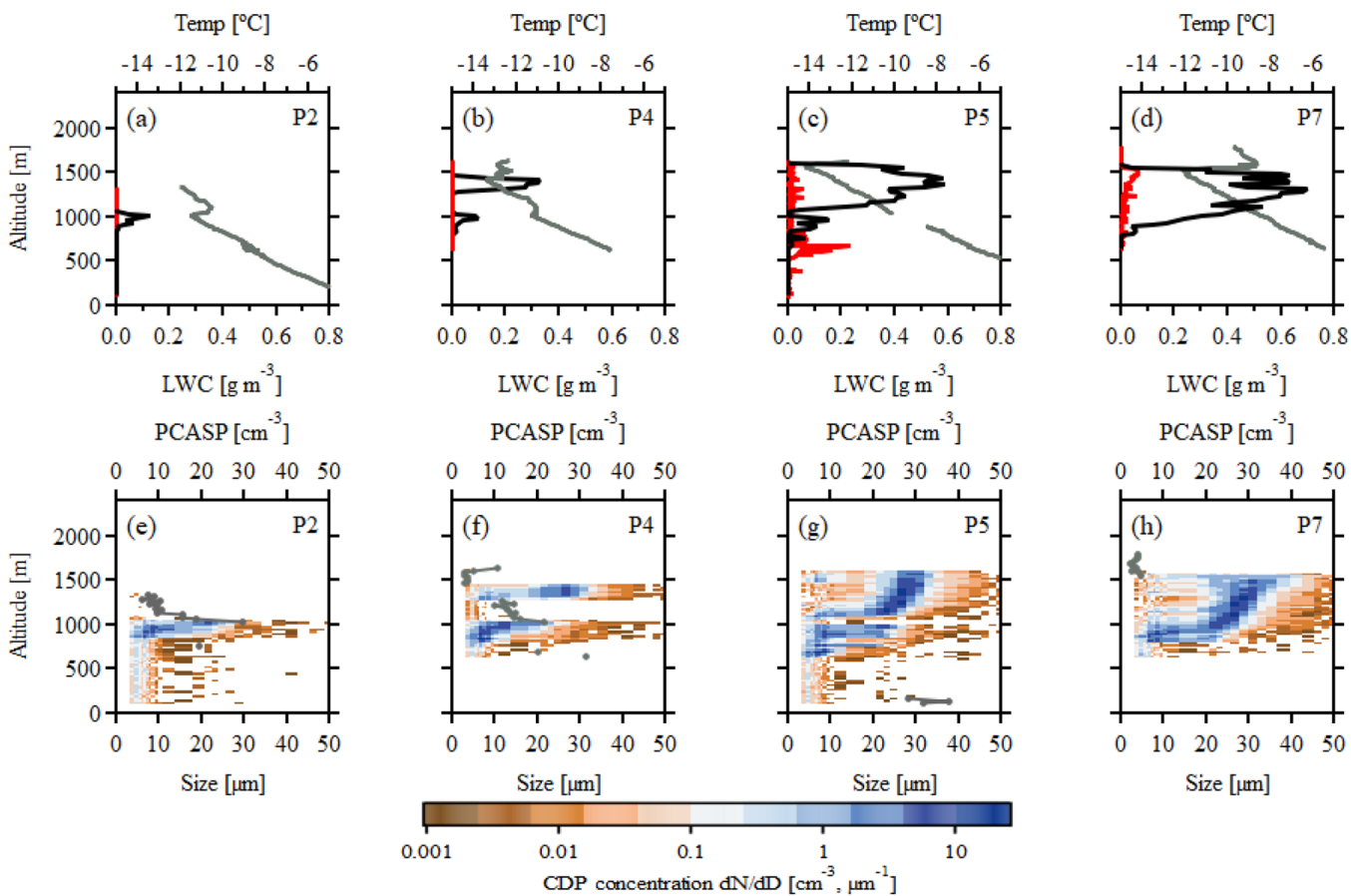

Figure 11. As Fig. 5 but for P2, P4, P5 and P7 for Case 3.
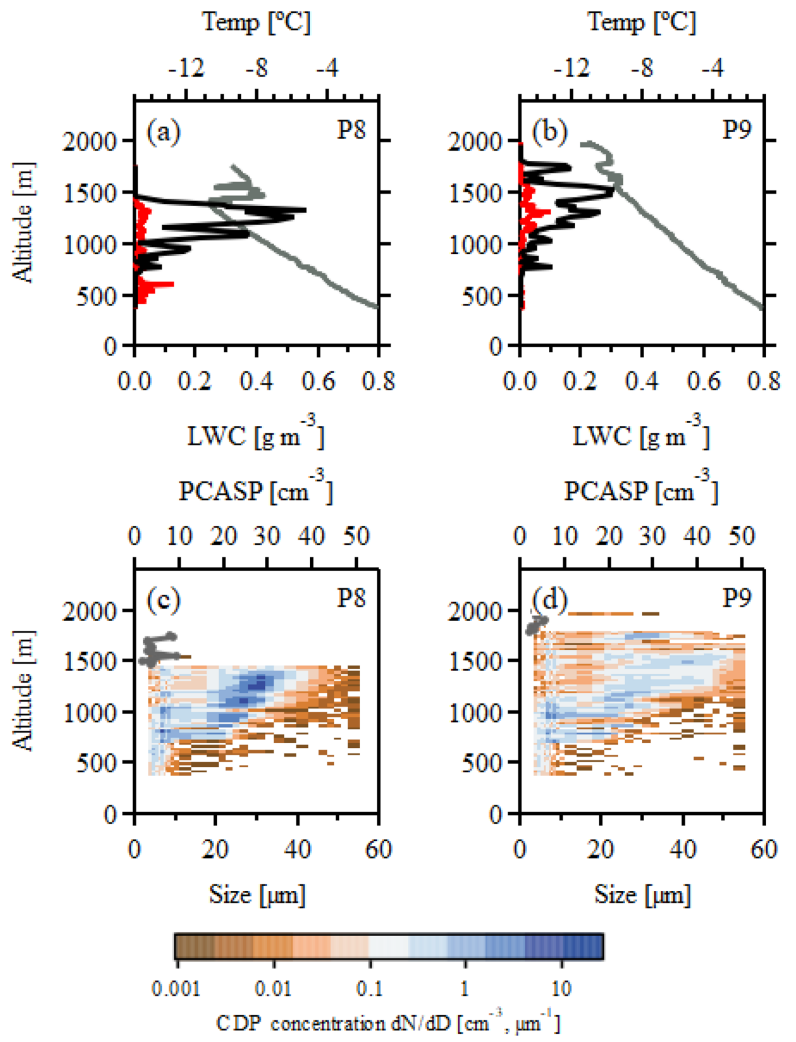

Figure 12. As Fig. 5 but for P8 and P9 for Case 3. ers (Fig. 3d), initially close to the Shetland Isles, but then with increasing distance south along the east coast of England. Profiles through SCs covered a large area from approximately 60 to $61^{\circ} \mathrm{N}$.

In situ measurements at the north end of the measurement region (Fig. 3d) revealed a region of SCs below a temperature inversion around $1750 \mathrm{~m}$. Earlier dropsondes deployed by the aircraft (marked on Fig. 3d) had found the inversion to be between about 1500 and $2000 \mathrm{~m}$. The dropsonde profile deeper in the stratiform region had a stronger inversion and lower cloud top height compared to the dropsonde in the transition region. Cloud tops were quite variable in this case and generally between 1500 and $1750 \mathrm{~m}$ (Fig. 4d). Cloud bases were anywhere from $\sim 1000$ to $1500 \mathrm{~m}$. Cloud top temperatures were between -8 and $-14^{\circ} \mathrm{C}$. Cloud base temperatures were between -6 and $-9{ }^{\circ} \mathrm{C}$.

LWP values measured by the CDP and MARSS (Fig. 3d) were generally around $200 \mathrm{~g} \mathrm{~m}^{-2}$ in the stratiform region between 13:30 and 14:45 UTC. Microphysical properties as a function of altitude for selected profiles are shown in Fig. 14. These profiles from the overcast region (P3 and P8) compared with measurements made during profiles in an open cellular region identified on satellite imagery (P16 and P18). In the open cellular region a temperature inversion was still present; some profiles exhibited a thin liquid cloud layer below this inversion and others were clear. In the stratiform region, LWC values peaked at $\sim 0.8$ (Fig. 14a-b). During the transition, values were much lower around $0.2 \mathrm{~g} \mathrm{~m}^{-3}$. This change can also be seen in the LWP values (Fig. 3d) that de- 


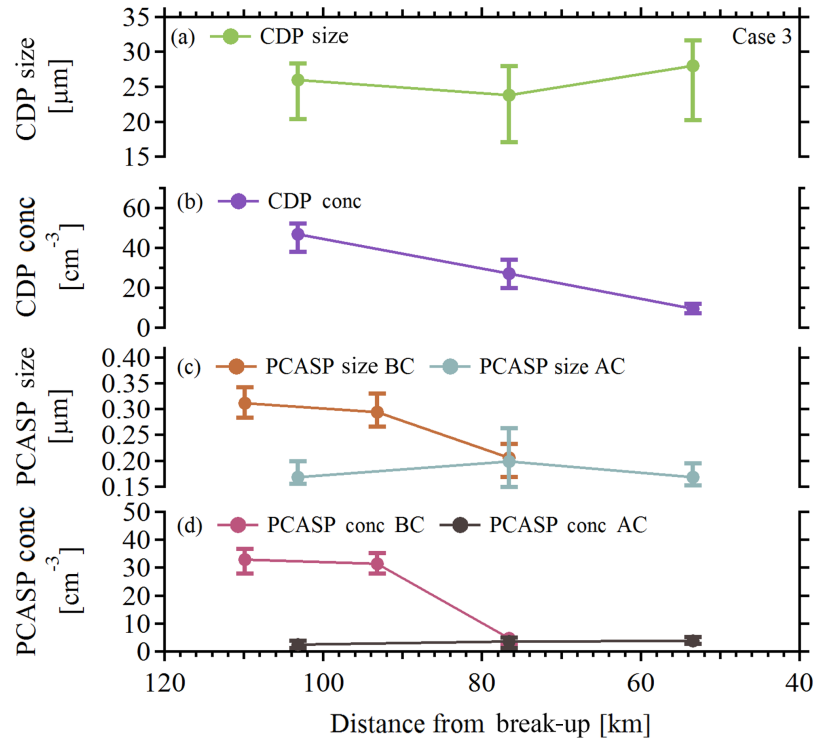

Figure 13. Median and 25th and 75th percentile values as a function of distance from the break-up for CDP size, CDP concentration, PCASP size below cloud, PCASP size above cloud, PCASP concentration below cloud and PCASP concentration above cloud (Case 3).

crease first to $150 \mathrm{~g} \mathrm{~m}^{-2}$ at the transition and then to around $50 \mathrm{~g} \mathrm{~m}^{-2}$ in the open region. This appeared to be due to the cloud layer either breaking up completely or the persistence of a thin stratus cloud.

\section{Discussion}

ECMWF ERA 5 reanalysis (Fig. 2) shows a range of northerly outbreaks that produce supercooled SC layers that were investigated over the North Atlantic during four CAOs. These extensive layers of SC were similar in overall structure, with the cloudy region situated below a temperature inversion around $2 \mathrm{~km}$ in a well-mixed boundary layer (Fig. 15). Visible satellite imagery (Figs. 1 and 3) shows that all cases eventually transitioned into an open cellular regime, with the SCs breaking up. In situ measurements by the aircraft were designed to capture the microphysical evolution of the cloudy boundary layer as the SCs transitioned into the open cellular regime.

LWPs in the cloudy region derived in each case through in situ and remote sensing measurements on the aircraft were generally between 200 and $500 \mathrm{~g} \mathrm{~m}^{-2}$ (Fig. 3). These values showed a trend to much lower values in the regions of transition (often $<200 \mathrm{~g} \mathrm{~m}^{-2}$ ).

Case 1 provided observations of decreasing aerosol concentrations in the boundary layer (Fig. 6) with proximity to the transition region. This change was independent of the above cloud aerosol, which showed no obvious trend. Formation of drizzle, dendritic and irregular ice particles was observed, with these precipitating from the cloud layer. Imagery of these particles for the cases can be found in Fig. 8 .

It is thought the changes in aerosol below cloud were due to the removal of aerosol particles by precipitation scavenging processes. The removal rate, in the absence of any significant source of replenishment, leads to larger cloud droplets and increased efficiency of the warm rain process, further enhancing precipitation and loss of water from the cloud, which Abel et al. (2017) found to be a key factor in the transition and break-up of the clouds during these events.

Case 2 involved a CAO to the north-west of the UK. This case was in contrast to the other three cases, as aerosol properties in the boundary layer did not show an overall trend of declining number concentrations and actually demonstrated increasing concentrations of aerosol and cloud droplet numbers closer to the break-up (Fig. 10). In Case 2 the main difference in the meteorological conditions was the presence of high winds in the boundary layer, in excess of those observed in the other cases. It is proposed that in this situation replenishment of the aerosol population occurred from the sea surface, something that did not happen as much in the other cases. The production of sea salt over the oceans has been found to be strongly dependent on the wind speed close to the surface (Grythe et al., 2014). This has direct implications for cloud microphysical properties as the droplet size distribution and potentially the availability of ice nucleating particles is modulated

Case 3 provided observations of a $\mathrm{CAO}$ off the west coast of Iceland. SC layers, consisting predominantly of liquid and low concentrations of ice, were observed to deepen with increasing LWPs. This is consistent with the production of larger cloud hydrometeors promoting the formation of precipitation and the removal of increasing amounts of water from the cloud. This can be seen in Fig. 13a, where droplet sizes measured by the CDP increase with proximity to the break-up region. The aerosol measurements show that boundary layer concentrations are decreasing with distance south, closer to the break-up, and that cloud droplet sizes are increasing, which would in turn increase the efficiency of the warm rain process.

Case 4 revealed SC layers with varying amounts of drizzle and irregular ice particles deep within the SC layer, but much less ice further south, and with drizzle almost completely dominating the precipitation. As with Cases 1 and 3 , aerosol concentrations were observed to decrease in the boundary layer with distance travelled south.

In all cases the SCs were situated over a temperature range that was not ideal for secondary ice production to take place through the Hallett-Mossop (H-M) process. Generally cloud bases, particularly further north, were at the lower end of the $\mathrm{H}-\mathrm{M}$ temperature zone, leading to inefficient production of ice splinters through riming. In some cases, secondary ice production was observed; for example, in Case 1, instability in the boundary layer allowed cumulus to grow through the $\mathrm{H}-\mathrm{M}$ temperature zone, penetrating the SC layers above. In 

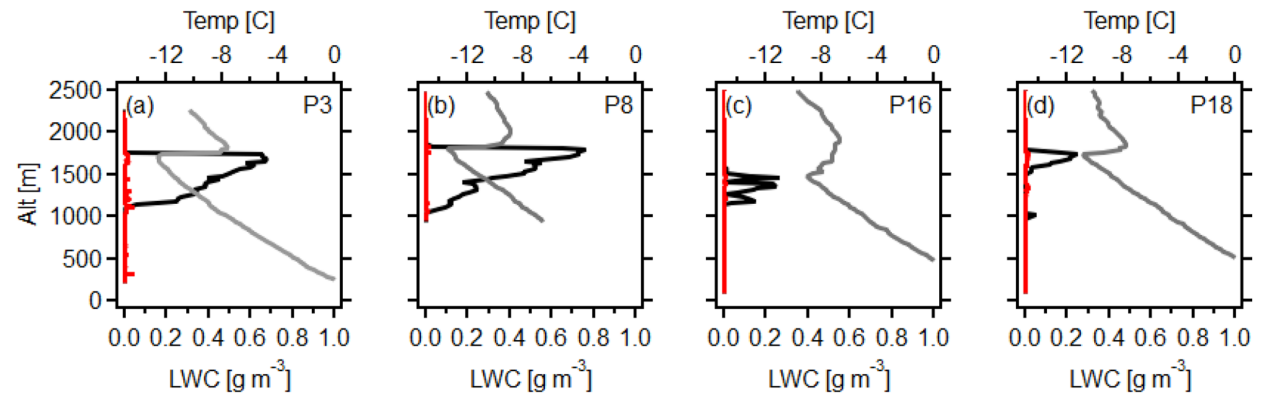

Figure 14. LWC (black trace) and temperature (grey trace) as a function of altitude for selected profiles from Case 4 .
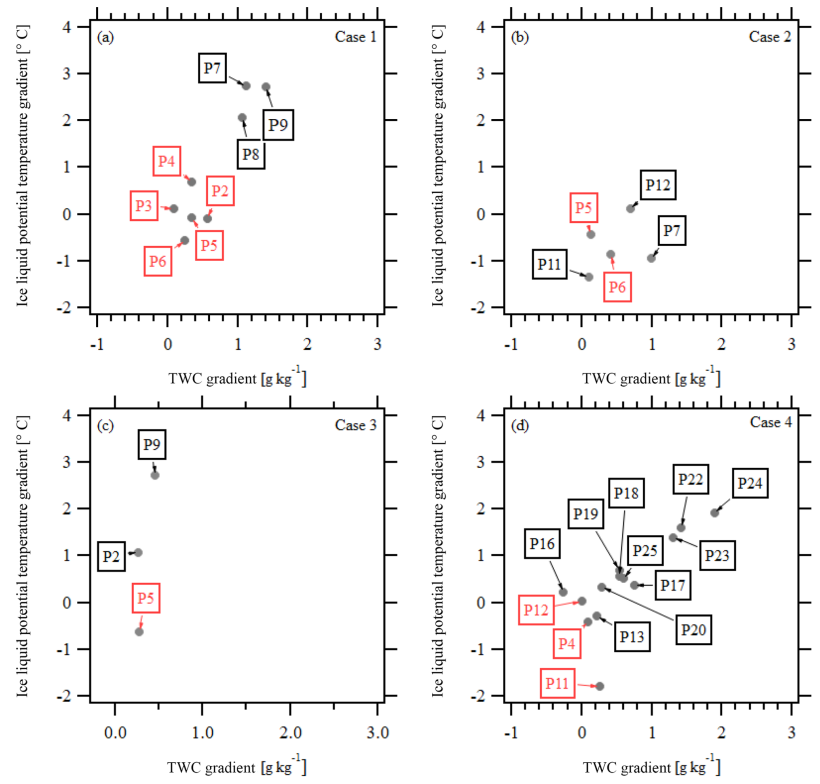

Figure 15. Gradients in $\Delta \theta_{\mathrm{il}}$ vs. $\Delta q_{\mathrm{t}}$ for Cases $1-4$. Red profile numbers represent gradients within the stratiform boundary layer and black profile numbers represent gradients in transition or open regions.

this case, high concentrations of ice were observed, with the rapid depletion of liquid water.

Together with the cloud not being in an ideal environment for $\mathrm{H}-\mathrm{M}$ secondary ice production, the clouds were also generally warmer than $-15^{\circ} \mathrm{C}$, the temperature at which most dust becomes significant as active INPs (Hoose and Möhler, 2012). This is consistent with limited amounts of primary ice nucleation, and when it did occur, the riming particles that were generated descended through a temperature range not conducive to secondary ice production.

Case 1 discussed in this paper describes the CAO investigated by Abel et al. (2017) through both in situ measurements and modelling sensitivity tests. We have found in a further three cases in the North Atlantic region that in situ measurements of their microphysical properties are broadly similar. Predominantly liquid cloud layers contained LWPs of several $100 \mathrm{~g} \mathrm{~m}^{-2}$ before reducing significantly as the cloud evolved into an open cellular regime.

We also confirm the observation of low numbers of ice crystal concentrations, the understanding of which is key to accurately simulating these clouds in NWP models. In two of the additional cases, we also observed the removal of aerosol particles from the boundary layer with increasing proximity to the break-up region. In the other new case, this trend was not observed and we can only speculate that higher wind speeds in the boundary layer helped to replenish aerosol from the sea surface. Figure 16 shows an inter-case comparison on the same distance to break-up scale for the properties presented in Figs. 6, 10 and 13. This confirms that in Case 1 and 3 we see trends that are consistent with each other, for example decreasing aerosol concentrations and decreasing droplet number concentrations. Together with the similar trends, the values of microphysical properties also show some consistency between Cases 1 and 3. Concentrations of droplets, for example, are around $50 \mathrm{~cm}^{-3} \sim 110 \mathrm{~km}$ from the break-up in both Cases 1 and 3 .

Abel et al. (2017) provided evidence for boundary layer decoupling in Case 1 by calculating the gradients in ice liquid potential temperature $\left(\Delta \theta_{\mathrm{il}}{ }^{\circ} \mathrm{C}\right)$ and total water content $\left(\Delta q_{\mathrm{t}} \mathrm{g} \mathrm{kg}^{-1}\right)$ between the surface and top of the boundary layer. They found evidence that total water mixing ratios and liquid potential temperature were both well mixed to the top of the boundary layer. Closer to the transition region, increasing values of $\Delta \theta_{\mathrm{il}}$ and $\Delta q_{\mathrm{t}}$ were observed, indicating drizzleinduced decoupling of the boundary layer. Abel et al. (2017) also investigated the potential for cloud top entrainment instability (CTEI) following the calculation of parameter $k$ detailed in Lock (2009). Values of $k>0.2$ are indicative of entrainment at the cloud top, which is conducive to generating negatively buoyant mixtures that sink, promoting a break-up of the cloud. We also calculated this parameter, finding the values to be similar to values found by Abel et al. (2017), suggesting CTEI was not a driver for the break-up in these cases.

We also carried out the boundary layer decoupling calculations, and these have been applied for the cases presented here (Fig. 15). We also find evidence for the process 


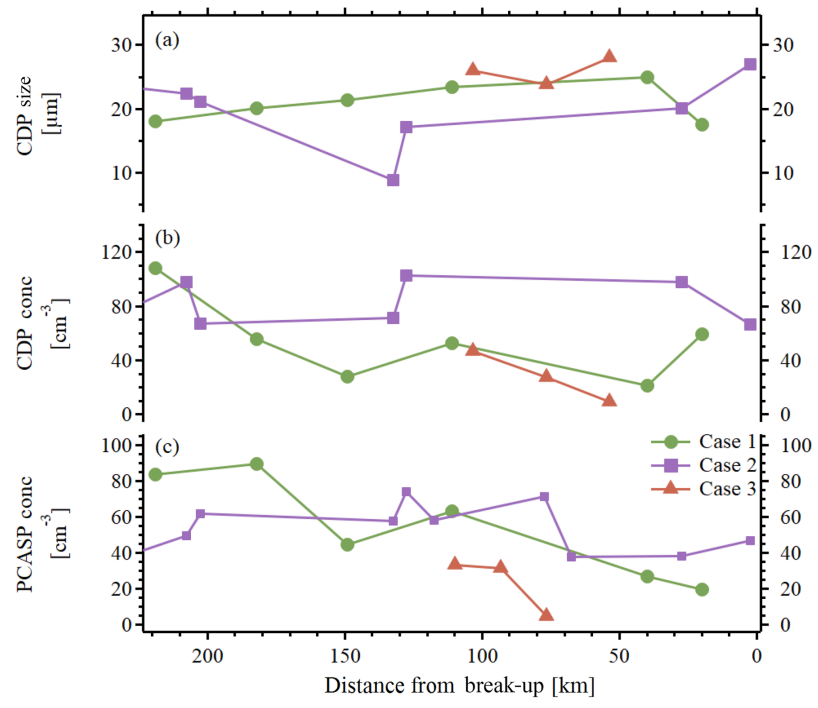

Figure 16. Median and 25th and 75th percentile values as a function of distance from the break-up for CDP size, CDP concentration, PCASP concentration below cloud and PCASP concentration above cloud for Cases 1, 2 and 3.

of drizzle-driven decoupling in some of the other cases. Red profile markers represent gradients in the stratiform region for each case, and black markers gradients in the transition or open cellular regions. Case 2 was quite different from the other cases in its microphysical evolution, and no real relationship is seen. The reasons for this are uncertain, but the strong wind speeds in this case would increase shear-induced turbulence, which could keep the boundary layer fairly well mixed, potentially slowing the transition. This well-mixed profile would help prevent the decoupling mechanism discussed in Case 1 and would also replenish aerosol, reducing the efficiency of any washout-precipitation feedback.

In Case 3 there was a lack of suitable measurements in general, but the profile closest to the transition did have increased gradients. In Case 4 we found strong evidence for this boundary layer decoupling metric being associated with the transition and open cellular regions.

\section{Conclusions}

In situ measurements of four CAOs over the North Atlantic were conducted to investigate the microphysical structure of SC layers and aerosol concentrations in the boundary layer. In all cases, measurements were continued through to the transition region where cloud layers became disrupted, leading to open cellular convection. The main findings from this study are outlined below.

- Extensive regions of SCs below a temperature inversion were observed in all cases, with these layers eventually breaking up into open cellular convection.
- The further three cases studied over the Abel et al. (2017) case are broadly similar in relation to their structure and evolution. This suggests that the results and model improvements detailed in Abel et al. (2017) can be applied more widely to help improve NWP of these types of events.

- The cloud layers in all cases were about $1 \mathrm{~km}$ in depth, with cloud top temperatures often warmer than $-15^{\circ} \mathrm{C}$, and with cloud bases colder than or at the colder end of the H-M SIP temperature range (between -3 and $-8^{\circ} \mathrm{C}$ ). Cloud temperatures increased with distance south. This sometimes led to increases in concentrations of columnar ice crystals as often associated with secondary ice production through the $\mathrm{H}-\mathrm{M}$ process.

- In three cases, aerosol properties in the boundary layer showed evidence of a decline in concentration (independent of the above cloud aerosol numbers) with increasing proximity to the transition zone. This has similarities to findings from VOCALS in the eastern Southern Hemisphere Pacific, where precipitation formation through collision coalescence led to the removal of aerosol particles at a rate that exceeded any replenishment. This creates a positive feedback, whereby cloud droplet size increases, together with the efficiency of the warm rain process and eventually the formation of precipitation. This feedback depletes the cloud of water, leading to cloud break-up.

- One case exhibited no apparent trend in aerosol concentrations in the boundary layer. This case was interesting as winds close to the surface were much higher than in other cases. One hypothesis is that replenishment of aerosol from the sea surface due to high wind speeds in the boundary layer offset any losses due to precipitation.

- Precipitation development appeared to be a key process in the evolution of the SC layers and their eventual break-up. All cases developed significant amounts of drizzle that precipitated from the cloud layers.

- Key to the formation of drizzle precipitation in some cases was the increasing size of liquid droplets measured by the CDP as shown in Fig. 6 and Fig. 13.

- The ice phase did vary between cases, with generally low concentrations of ice (a few $\mathrm{L}^{-1}$ ) present that appeared to be dependent on cloud top temperature and on whether clouds occupied a significant proportion of the $\mathrm{H}-\mathrm{M}$ temperature range. Cases 3 and 4 contained relatively little ice; however Cases 1 and 2 contained higher concentrations of ice, particularly Case 1 , in which dendritic ice crystals were observed deep within the SC region, and eventually high concentrations $\left(120 \mathrm{~L}^{-1}\right)$ of columnar ice crystals developed as the boundary layer 
became more unstable and cloud spanned the H-M temperature zone.

- Evidence was found to support the findings of Abel et al. (2017) that small gradients in $\Delta \theta_{\mathrm{il}}$ and $\Delta q_{\mathrm{t}}$ are associated with the stratiform, well-mixed boundary layer. Larger values of these parameters were more likely to be found in transition regions, indicating a decoupled boundary layer. It is suggested that this decoupling of the boundary layer close to the break-up zone inhibited the transport of water vapour from the sea surface to the cloud to offset losses.

Data availability. The data presented in this paper are available through the Centre for Environmental Data Analysis (CEDA) at http://catalogue.ceda.ac.uk/uuid/ 01b606c523154f7693956e5e0f0a92f1 (Facility for Airborne Atmospheric Measurements; Natural Environment Research Council; Met Office, 2014).

Author contributions. All authors contributed to the research and preparation of the paper.

Competing interests. The authors declare that they have no conflict of interest.

Acknowledgements. Airborne data were obtained using the FAAM BAe-146 Atmospheric Research Aircraft, which was operated by Airtask and jointly funded by the UK Natural Environment Research Council (NERC) and the Met Office. We acknowledge support from NERC under grant NE/I028696/1 as part of the Aerosol-Cloud Coupling and Climate Interactions in the Arctic (ACCACIA) project.

Edited by: Radovan Krejci

Reviewed by: two anonymous referees

\section{References}

Abel, S. J., Cotton, R. J., Barrett, P. A., and Vance, A. K.: A comparison of ice water content measurement techniques on the FAAM BAe-146 aircraft, Atmos. Meas. Tech., 7, 3007-3022, https://doi.org/10.5194/amt-7-3007-2014, 2014.

Abel, S. J., Boutle, I. A., Waite, K., Fox, S., Brown, P. R. A., Cotton, R., Lloyd, G., Choularton, T. W., and Bower, K. N.: The Role of Precipitation in Controlling the Transition from Stratocumulus to Cumulus Clouds in a Northern Hemisphere Cold-Air Outbreak, J. Atmos. Sci., 74, 2293-2314, https://doi.org/10.1175/JAS-D16-0362.1, 2017.

Baumgardner, D., Jonsson, H., Dawson, W., O'Connor, D., and Newton, R.: The cloud, aerosol and precipitation spectrometer: a new instrument for cloud investigations, Atmos. Res.,
59-60, 251-264, https://doi.org/10.1016/S0169-8095(01)001193, 2001.

Bodas-Salcedo, A., Williams, K. D., Field, P. R., and Lock, A. P.: The surface downwelling solar radiation surplus over the southern ocean in the met office model: The role of midlatitude cyclone clouds, J. Climate, 25, 7467-7486, https://doi.org/10.1175/JCLI-D-11-00702.1, 2012.

Boers, R., Jensen, J. B., Krummel, P. B., and Gerber, H.: Microphysical and short-wave radiative structure of wintertime stratocumulus clouds over the Southern Ocean, Q. J. Roy. Meteor. Soc., 122, 1307-1339, 1996.

Boutle, I. A. and Abel, S. J.: Microphysical controls on the stratocumulus topped boundary-layer structure during VOCALS-REx, Atmos. Chem. Phys., 12, 2849-2863, https://doi.org/10.5194/acp-12-2849-2012, 2012.

Bretherton, C. S. and Wyant, M. C.: Moisture Transport, Lower-Tropospheric Stability, and Decoupling of Cloud-Topped Boundary Layers, J. Atmos. Sci., 54, 148-167, https://doi.org/10.1175/15200469(1997)054<0148:MTLTSA>2.0.CO;2, 1997.

Connolly, P. J., Vaughan, G., Cook, P., Allen, G., Coe, H., Choularton, T. W., Dearden, C., and Hill, A.: Modelling the effects of gravity waves on stratocumulus clouds observed during VOCALS-UK, Atmos. Chem. Phys., 13, 7133-7152, https://doi.org/10.5194/acp-13-7133-2013, 2013.

Crosier, J., Bower, K. N., Choularton, T. W., Westbrook, C. D., Connolly, P. J., Cui, Z. Q., Crawford, I. P., Capes, G. L., Coe, H., Dorsey, J. R., Williams, P. I., Illingworth, A. J., Gallagher, M. W., and Blyth, A. M.: Observations of ice multiplication in a weakly convective cell embedded in supercooled mid-level stratus, Atmos. Chem. Phys., 11, 257-273, https://doi.org/10.5194/acp-11257-2011, 2011.

Curry, J. A., Rossow, W. B., Randall, D., and Schramm, J. L.: Overview of Arctic Cloud and Radiation Characteristics, J. Climate, 9, 1731-1764, 1996.

Facility for Airborne Atmospheric Measurements; Natural Environment Research Council; Met Office: PIKNMIX: in-situ airborne observations by the FAAM BAE-146 aircraft, NCAS British Atmospheric Data Centre, available at: http://catalogue. ceda.ac.uk/uuid/01b606c523154f7693956e5e0f0a92f1 (last access: 13 November 2018), 2014.

Field, P. R., Cotton, R. J., Mcbeath, K., Lock, A. P., Webster, S., and Allan, R. P.: Improving a convection-permitting model simulation of a cold air outbreak, Q. J. Roy. Meteor. Soc., 140, 124 138, https://doi.org/10.1002/qj.2116, 2014.

Field, P. R., Brožková, R., Chen, M., Dudhia, J., Lac, C., Hara, T., Honnert, R., Olson, J., Siebesma, P., de Roode, S., Tomassini, L., Hill, A., and McTaggart-Cowan, R.: Exploring the convective grey zone with regional simulations of a cold air outbreak, Q. J. Roy. Meteor. Soc., 143, 2537-2555, https://doi.org/10.1002/qj.3105, 2017.

Fletcher, J., Mason, S., and Jakob, C.: The climatology, meteorology, and boundary layer structure of marine cold air outbreaks in both hemispheres, J. Climate, 29, 1999-2014, https://doi.org/10.1175/JCLI-D-15-0268.1, 2016.

Grythe, H., Ström, J., Krejci, R., Quinn, P., and Stohl, A.: A review of sea-spray aerosol source functions using a large global set of sea salt aerosol concentration measurements, Atmos. 
Chem. Phys., 14, 1277-1297, https://doi.org/10.5194/acp-141277-2014, 2014.

Hoose, C. and Möhler, O.: Heterogeneous ice nucleation on atmospheric aerosols: a review of results from laboratory experiments, Atmos. Chem. Phys., 12, 9817-9854, https://doi.org/10.5194/acp-12-9817-2012, 2012.

Jackson, R. C., McFarquhar, G. M., Korolev, A. V., Earle, M. E., Liu, P. S. K., Lawson, R. P., Brooks, S., Wolde, M., Laskin, A., and Freer, M.: The dependence of ice microphysics on aerosol concentration in arctic mixed-phase stratus clouds during ISDAC and M-PACE, J. Geophys. Res.-Atmos., 117, 1-20, https://doi.org/10.1029/2012JD017668, 2012.

Kay, J. E., Wall, C., Yettella, V., Medeiros, B., Hannay, C., Caldwell, P., and Bitz, C.: No access global climate impacts of fixing the Southern Ocean shortwave radiation bias in the Community Earth System Model (CESM), J. Climate, 29, 4617-4636, https://doi.org/10.1175/JCLI-D-15-0358.1, 2016.

Klein, S. A., McCoy, R. B., Morrison, H., Ackerman, A. S., Avramov, A., Boer, G. de, Chen, M., Cole, J. N. S., Del Genio, A. D., Falk, M., and others: Intercomparison of model simulations of mixed-phase clouds observed during the ARM Mixed-Phase Arctic Cloud Experiment. I: Single-layer cloud, Q. J. Roy. Meteor. Soc., 135, 979-1002, 2009.

Kolstad, E. W., Bracegirdle, T. J., and Seierstad, I. A.: Marine coldair outbreaks in the North Atlantic: temporal distribution and associations with large-scale atmospheric circulation, Clim. Dynam., 33, 187-197, 2009.

Korolev, A. V., Strapp, J. W., Isaac, G. A., and Nevzorov, A. N.: The Nevzorov airborne hot-wire LWC-TWC probe: principle of operation and performance characteristics, J. Atmos. Ocean.-Tech., 15, 1495-1510, https://doi.org/10.1175/15200426(1998)015<1495:Tnahwl>2.0.Co;2, 1999.

Korolev, A. V., Emery, E. F., Strapp, J. W., Cober, S. G., Isaac, G. A., Wasey, M., and Marcotte, D.: Small ice particles in tropospheric clouds: fact or artifact?, B. Am. Meteorol. Soc., 92, 967-973, https://doi.org/10.1175/2010BAMS3141.1, 2011.

Lance, S., Brock, C. A., Rogers, D., and Gordon, J. A.: Water droplet calibration of the Cloud Droplet Probe (CDP) and in-flight performance in liquid, ice and mixed-phase clouds during ARCPAC, Atmos. Meas. Tech., 3, 1683-1706, https://doi.org/10.5194/amt-3-1683-2010, 2010.

Lance, S., Shupe, M. D., Feingold, G., Brock, C. A., Cozic, J., Holloway, J. S., Moore, R. H., Nenes, A., Schwarz, J. P., Spackman, J. R., Froyd, K. D., Murphy, D. M., Brioude, J., Cooper, O. R., Stohl, A., and Burkhart, J. F.: Cloud condensation nuclei as a modulator of ice processes in Arctic mixed-phase clouds, Atmos. Chem. Phys., 11, 8003-8015, https://doi.org/10.5194/acp11-8003-2011, 2011.

Lawson, P. R., O’Connor, D., Zmarzly, P., Weaver, K., Baker, B., and Mo, Q.: The 2D-S (stereo) probe: design and preliminary tests of a new airborne high-speed, high resolution particle imagine probe, J. Atmos. Ocean. Tech., 23, 1462-1477, 2006

Liu, X., Xie, S., Boyle, J., Klein, S. A., Shi, X., Wang, Z., Lin, W., Ghan, S. J., Earle, M., Liu, P. S. K., and Zelenyuk, A.: Testing cloud microphysics parameterizations in NCAR CAM5 with ISDAC and M-PACE observations, J. Geophys. Res.-Atmos., 116, 1-18, https://doi.org/10.1029/2011JD015889, 2011.

Lloyd, G., Choularton, T. W., Bower, K. N., Crosier, J., Jones, H., Dorsey, J. R., Gallagher, M. W., Connolly, P., Kirchgaessner, A.
C. R., and Lachlan-Cope, T.: Observations and comparisons of cloud microphysical properties in spring and summertime Arctic stratocumulus clouds during the ACCACIA campaign, Atmos. Chem. Phys., 15, 3719-3737, https://doi.org/10.5194/acp15-3719-2015, 2015.

Lock, A. P.: Factors influencing cloud area at the capping inversion for shallow cumulus clouds, Q. J. Roy. Meteor. Soc., 135, 941952, https://doi.org/10.1002/qj.424, 2009.

McGrath, A. and Hewison, T.: Measuring the accuracy of MARSS - An airborne microwave radiometer, J. Atmos. Ocean. Tech., 18, 2003-2012, https://doi.org/10.1175/15200426(2001)018<2003:MTAOMA>2.0.CO;2, 2001.

Morrison, H. and Pinto, J. O.: Intercomparison of Bulk Cloud Microphysics Schemes in Mesoscale Simulations of Springtime Arctic Mixed-Phase Stratiform Clouds, Mon. Weather Rev., 134, 1880-1900, https://doi.org/10.1175/MWR3154.1, 2006.

Nicholls, S., Leighton, J., and Barker, R.: A new fast response instrument for measuring total water content from aircraft, J. Atmos. Ocean. Tech., 7, 706-718, 1990.

Rosenfeld, D., Lohmann, U., Raga, G. B., O’Dowd, C. D., Kulmala, M., Fuzzi, S., Reissell, A., and Andreae, M. O.: Flood or Drought: How Do Aerosols Affect Precipitation?, Science, 321, 1309-1313, https://doi.org/10.1126/science.1160606, 2008.

Rosenberg, P. D., Dean, A. R., Williams, P. I., Dorsey, J. R., Minikin, A., Pickering, M. A., and Petzold, A.: Particle sizing calibration with refractive index correction for light scattering optical particle counters and impacts upon PCASP and CDP data collected during the Fennec campaign, Atmos. Meas. Tech., 5, 1147-1163, https://doi.org/10.5194/amt-5-1147-2012, 2012.

Stevens, B., Vali, G., Comstock, K., Wood, R., van Zanten, M. C., Austin, P. H., Bretherton, C. S., and Lenschow, D. H.: Pockets of open cells and drizzle in marine stratocumulus, B. Am. Meteorol. Soc., 86, 51-57, https://doi.org/10.1175/BAMS-86-1-51, 2005.

Terai, C. R., Bretherton, C. S., Wood, R., and Painter, G.: Aircraft observations of aerosol, cloud, precipitation, and boundary layer properties in pockets of open cells over the southeast Pacific, Atmos. Chem. Phys., 14, 8071-8088, https://doi.org/10.5194/acp14-8071-2014, 2014.

Verlinde, J., Harrington, J. Y., Yannuzzi, V. T., Avramov, A., Greenberg, S., Richardson, S. J., Bahrmann, C. P., McFarquhar, G. M., Zhang, G., Johnson, N. Zhang, G., Poellot, M. R., Mather, J. H., Turner, D. D., Eloranta, E. W., Zak, B. D., Prenni, A. J., Daniel, J. S., Kok, G. L., Tobin, D. C., Holz, R., Sassen, K., Spangenberg, D., Minnis, P., Tooman, T. P., Ivey, M. D., Richardson, S. J., Bahrmann, C. P., Shupe, M., DeMott, P. J., Heymsfield, A. J., and Schofield, R.: The mixed-phase Arctic cloud experiment, B. Am. Meteorol. Soc., 88, 205-221, 2007.

Wood, R., Comstock, K. K., Bretherton, C. S., Cornish, C., Tomlinson, J., Collins, D. R., and Fairall, C.: Open cellular structure in marine stratocumulus sheets, J. Geophys. Res.-Atmos., 113, 1-16, https://doi.org/10.1029/2007JD009371, 2008.

Wood, R., Bretherton, C. S., Leon, D., Clarke, A. D., Zuidema, P., Allen, G., and Coe, H.: An aircraft case study of the spatial transition from closed to open mesoscale cellular convection over the Southeast Pacific, Atmos. Chem. Phys., 11, 2341-2370, https://doi.org/10.5194/acp-11-2341-2011, 2011 a.

Wood, R., Mechoso, C. R., Bretherton, C. S., Weller, R. A., Huebert, B., Straneo, F., Albrecht, B. A., Coe, H., Allen, G., Vaughan, G., Daum, P., Fairall, C., Chand, D., Gallardo Klenner, L., Garreaud, 
R., Grados, C., Covert, D. S., Bates, T. S., Krejci, R., Russell, L. M., de Szoeke, S., Brewer, A., Yuter, S. E., Springston, S. R., Chaigneau, A., Toniazzo, T., Minnis, P., Palikonda, R., Abel, S. J., Brown, W. O. J., Williams, S., Fochesatto, J., Brioude, J., and Bower, K. N.: The VAMOS Ocean-Cloud-AtmosphereLand Study Regional Experiment (VOCALS-REx): goals, platforms, and field operations, Atmos. Chem. Phys., 11, 627-654, https://doi.org/10.5194/acp-11-627-2011, 2011 b.
Yamaguchi, T., Feingold, G., and Kazil, J.: Stratocumulus to Cumulus Transition by Drizzle, J. Adv. Model. Earth Syst., 9, 23332349, https://doi.org/10.1002/2017MS001104, 2017. 